\title{
Tbilisi Through Time
}

\author{
Mariam Tsitsagi ${ }^{1}$, Nino Kharebava ${ }^{2 *}$, Dali Nikolaishvili ${ }^{2}$, Ia Kupatadze ${ }^{3}$, Lela Gadrani ${ }^{1}$
}

\begin{abstract}
Ancient cities have witnessed many changes throughout their long history. These changes have different underlying causes in different regions of the world. This paper discusses the urban sprawl of Tbilisi, the capital of Georgia, mainly from the beginning of the 19th century to 2020. Through analysis of historical materials, city plans, and old maps, layers of Tbilisi urban sprawl were created using ArcMap 10.8. Images of Landsat 5 TM and Landsat 8 OLI have been used to assess changes over the last 30 years. We compared the obtained data with the census data conducted during the study period, reconstructed the current social, political, and economic situation using historical sources, and finally determined in which period the urban expansion took place, the reasons for it, and how this expansion affected the natural and social environments of the city.
\end{abstract}

Keywords: urban sprawl, urban expansion, Tbilisi, Georgia

\section{Introduction}

Cities are an integral part of the modern environment. It is estimated that by 2050, approximately $50 \%$ of the Earth's population will live in cities and surrounding areas [1]. Urban areas are constantly changing in time and space, and different parts of the city are associated with different historical epochs. These changes are often included in the definition of "city" itself. For example, according to one definition, "cities are not things, cities are processes" [2]. It is therefore essential to study these processes. Archaeology and historical data provide information on the spatial transformation of cities [3], particularly urban sprawl, which is one of the accompanying processes of urban development. The character of sprawl varies by region, for example, in Europe and America, and there are also internal differences within Europe [4]. Many factors, such as population growth, land prices, transportation development, and political fragmentation [5], influence urban sprawl. As mentioned earlier, the factors and influences are different within the countries and regions. For example, the size of many European cities is growing faster than their populations, hence the growing demand for land around the cities [4].

Tbilisi is the largest and one of the oldest cities in Georgia. It is logical that, over 1500 years of existence, the development and configuration of the city have been linked to its land use and urban sprawl. Naturally, initially, but later intentionally, the city's structure has been formed and transformed through a series of brief interventions over time. These changes took place with varying intensities at different stages, and the main drivers also varied. Research on these issues has been conducted in the past, and studies on similar topics have been published $[6,7]$. In the present study, we want to focus on and deepen our knowledge of the drivers and consequences of urban sprawl in Tbilisi over the last two centuries.

The research aims to analyse changes in the urban area of Tbilisi through time to determine and identify the main directions and reasons for these changes. We will also explore how and why Tbilisi developed from a compact city into the urban structure it has today and what problems it may cause us in the future.

\section{Study Area}

Tbilisi, the capital city of Georgia, is located in the eastern part of the country, at the intersection of Eastern Europe and Western Asia, at $41^{\circ} 41^{\prime} \mathrm{N}$ and $44^{\circ} 47^{\prime} \mathrm{E}$. The capital is situated on both banks of the Mtkvari River. The section of the Mtkvari River valley (Tbilisi depression) from Zemo Avchala to Ponichala is characterized by complex terrain. The height of the bottom of the depression varies in the range of 350-450 m asl, and its slopes reach $1500 \mathrm{~m}$. In the north, it is bordered by the Saguramo Range, in the east and southeast by the Iori Upland, and in the south and west by the subranges of the Trialeti Range [8]. The city stretches $* 33 \mathrm{~km}$ along the Mtkvari River and occupies an area of $502 \mathrm{~km}^{2}$.

\footnotetext{
${ }^{1}$ Vakhushti Bagrationi Institute of Geography, TSU, Tbilisi, Georgia

${ }^{2}$ Faculty of Exact and Natural Silences, Ivane Javakhishvili Tbilisi State University, Georgia

${ }^{3}$ School of Technology, Ilia State University, Tbilisi, Georgia

* Corresponding author: kharebava.nino@gmail.com
} 


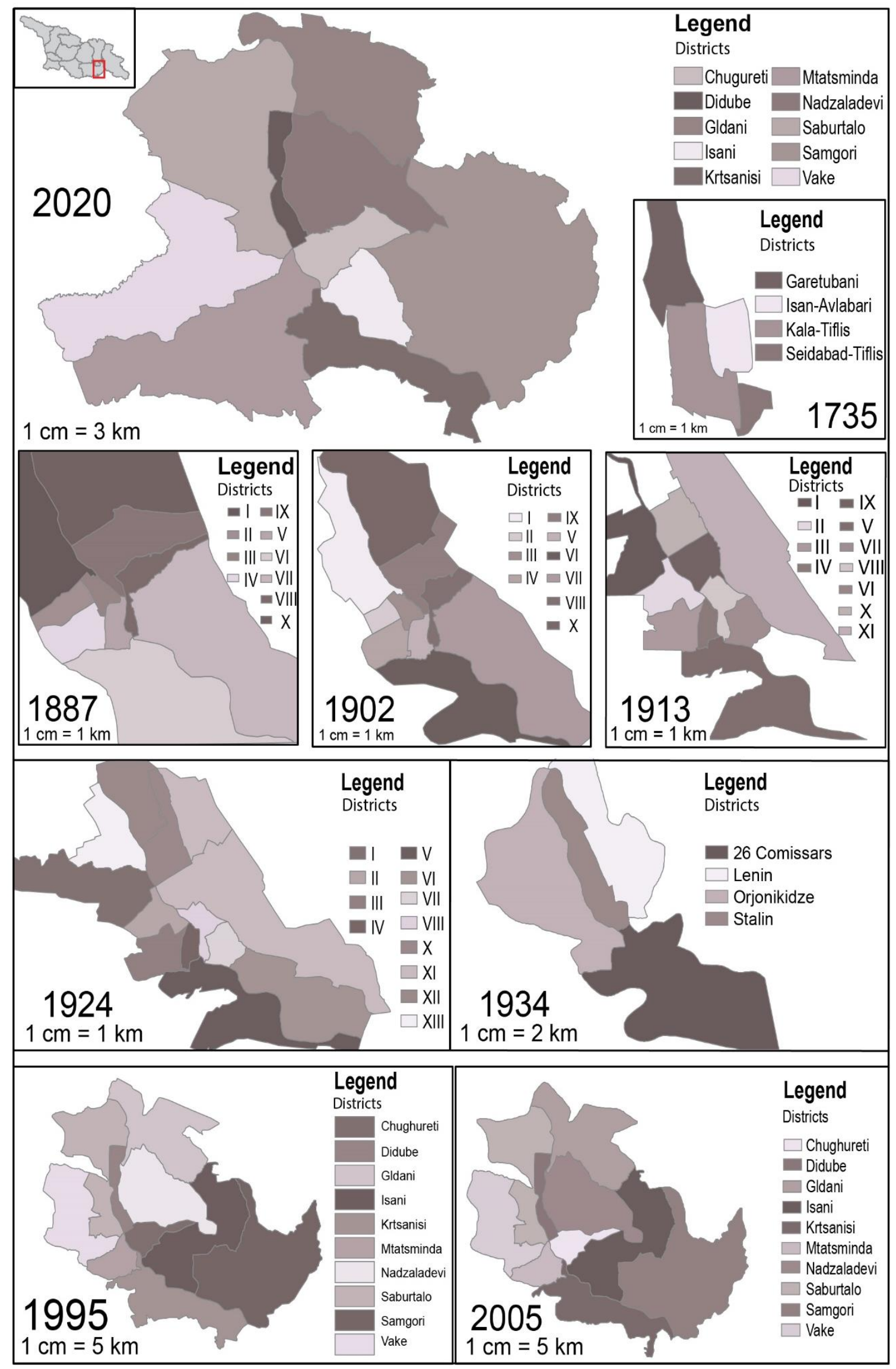

Figure 1. Changes in the area and administrative-territorial division of Tbilisi through time 
Tbilisi has been mentioned as a city since 458 AD. The city is an important political, economic and cultural centre. The first urban growth of Tbilisi dates back to the 19th century, after Georgia became subject to the Russian monarch. The city became the seat of the new governor and viceroy; therefore, new European-style buildings, railways and roads were constructed inside the settlement. In the 1850s, Tbilisi was reinvented as an essential political, cultural, commercial and administrative centre in the Southern Caucasus. The city had significant growth under Soviet rule. The second wave of urbanization erupted in the mid-20th century, with an influx of labourers and the emergence of factories and other similar facilities. By the year 1990, 17.4\% of the area of Tbilisi was an industrial zone.

\section{Methods and Materials}

There are many sources of information about Tbilisi, but most are not in digital format. This is especially true of old maps and city plans. It therefore became necessary to contrast the old cartographic sources with the modern basis. The research is based on old cartographic sources and current Remotely Sensed data. Several sources have been used in the study (Table 1).

Table 1. Data used in research

\begin{tabular}{lllll}
\hline$\#$ & Title & Year & \multicolumn{2}{c}{ Scale } \\
\hline 1 & Plan of Tbilisi by Vakhushti & 1735 & $1: 500000$ & $5000 \mathrm{~m}$ \\
\hline 2 & Plan of Tbilisi & 1800 & & \\
\hline 3 & New Plan of Tbilisi & 1828 & & \\
\hline 4 & Plan of Tbilisi & 1844 & $1: 4100$ & $41.3 \mathrm{~m}$ \\
\hline 5 & Plan of Tbilisi city and surroundings & 1867 & $1: 8400$ & $84.3 \mathrm{~m}$ \\
\hline 6 & Plan of Tbilisi city and surroundings & 1887 & $1: 11300$ & $113.7 \mathrm{~m}$ \\
\hline 7 & Plan of Tbilisi & 1902 & $1: 4100$ & $41.3 \mathrm{~m}$ \\
\hline 8 & Plan of Tbilisi & 1913 & $1: 8400$ & $84.3 \mathrm{~m}$ \\
\hline 9 & Plan of Tbilisi & 1924 & $1: 6000$ & $60 \mathrm{~m}$ \\
\hline 10 & Plan of Tbilisi (Scheme) & 1934 & $1: 8000$ & $80 \mathrm{~m}$ \\
\hline 11 & Topographic map of Tbilisi & 1955 & $1: 25000$ & $250 \mathrm{~m}$ \\
\hline 12 & General plan of Tbilisi & 1970 & $1: 10000$ & $100 \mathrm{~m}$ \\
\hline 13 & Landsat 5 TM & 1988 & $1: 3000$ & $30 \mathrm{~m}$ \\
\hline 14 & Landsat 5 TM & 2010 & $1: 3000$ & $30 \mathrm{~m}$ \\
\hline 15 & Landsat 8 OLI & 2020 & $1: 3000$ & $30 \mathrm{~m}$ \\
\hline
\end{tabular}

At the initial stage, a 1: 25,000 scale map of Tbilisi and its environs, consisting of 19 sheets, is used as a cartographic basis. On this basis we have connected the maps and plans of the 19th-20th centuries (Vakhushti Bagrationi, the so-called "Verstovki", Soviet topographic and modern maps, space images), which are composed of different scales and projections, and what is also very important - different cartography development Levels. This circumstance created some problems in terms of GIS registration and object matching. On the one hand, the map overlay provided good accuracy, and on the other hand, the complete disagreement of the objects. This is especially true when there is a large time difference between maps and also differences in mapping methods, coordinate systems, distances, and/or projections. Here, we have identified the objects on the old plans, identified their modern matches, and "mechanically transferred" the information from the old cartographic sources to the new base.

At the next stage, city plans were georeferenced. All maps were given projection WGS-84-38N. A green area and a built-up area were drawn from each map. In the next step, we defined the built-up and green areas from the Landsat $5 \mathrm{TM}$ and Landsat 8 OLI images using the LULC classification. We used Google Maps and large-scale maps to evaluate the accuracy of the results. The oldest data at our disposal was the Tbilisi plan drawn up by Vakhushti Bagrationi in 1735. According to this plan, the contours of the then settlements of Tbilisi were determined, the city centre was defined and using this center we determined the direction and speed of the development for each subsequent period. All operations were performed in the program ArcMap 10.8.

Data from various narrative sources were also used to identify and analyse land use patterns. This function was performed using both scientific sources and ancient data. The data in these sources were identified, compared and entered into the GIS database.

All the above made it possible to identify the space-time changes of Tbilisi land use, cartography, and anthropogenic quality of the area. 


\section{Results and Discussion}

The processing of existing materials, ancient cartographic sources has shown that we can distinguish several waves of urban sprawl in Tbilisi over the past two centuries. We have selected five periods in total and the underlying main drivers of these changes (Table 2). During these periods, specific districts were formed, and city structures was transformed - the relief construction, changes in the hydrographical set, destruction of natural green cover, etc. It should be noted that the changes were different in different periods.

Table 2. Stages of the urban expansion in Tbilisi

\begin{tabular}{|c|c|c|c|}
\hline & Period & Districts $^{2}$ & Main drivers \\
\hline 1 & pre- 1800 & $\begin{array}{l}\text { Sololaki, Kalaubani, Abanotubani, } \\
\text { Kharpukhi, Rike, Avlabari, former } \\
\text { Vorontsovi }\end{array}$ & $\begin{array}{l}\text { Environmental factors; the } \\
\text { terrain allowed for better } \\
\text { protection of the city, Mtkveri } \\
\text { river }\end{array}$ \\
\hline 2 & $1800-1850$ & $\begin{array}{l}\text { Chugureti, Vera, Mtatsminda, Isani, } \\
\text { Ortachala, Krtsanisi }\end{array}$ & $\begin{array}{l}\text { Population growth; Turning } \\
\text { Tbilisi into the geopolitical } \\
\text { center of the Caucasus }\end{array}$ \\
\hline 3 & $1850-1930$ & $\begin{array}{l}\text { Nadzaladevi, Didube, Svanetis ubani, } \\
\text { Kukia, Metromsheni, 8th Legion } \\
\text { Settlement, Navtlughi, Saburtalo, } \\
\text { Vake }\end{array}$ & $\begin{array}{l}\text { Population growth; Ongoing } \\
\text { social reforms in the empire }\end{array}$ \\
\hline 4 & $1930-1990$ & $\begin{array}{l}\text { Lotkini, Sanzona, } \begin{array}{r}\text { Dighomi, } \\
\text { Vashlijvari, Vedzisi, Delisi }\end{array} \text { Metro } \\
\text { Area, Dampalo, Military City, } \\
\text { Vazisubani, Varketili. }\end{array}$ & $\begin{array}{l}\text { Soviet period, } \\
\text { industrialization, natural and } \\
\text { mechanical population } \\
\text { growth, increased demand for } \\
\text { residential and commercial } \\
\text { space }\end{array}$ \\
\hline 5 & $\begin{array}{l}\text { 1990- } \\
\text { present day }\end{array}$ & $\begin{array}{l}\text { The village of Gldani, Zahesi, } \\
\text { mukhatgverdi, Telovani, Didgori, } \\
\text { Dzveli vedzisi, The village of Digomi, } \\
\text { Tkhilvani, Agaraki, Bagebi, } \\
\text { Okrokana, Tskneti, Akhaldaba, } \\
\text { Tsavkisi, Shindisi, Tabakhmela, } \\
\text { Kojori, Kiketi, Betania, Kveseti, Didi } \\
\text { Lilo }\end{array}$ & $\begin{array}{l}\text { Post-Soviet period, problems } \\
\text { of IDPs as a result of the } \\
\text { political crisis, increased } \\
\text { migration from rural to urban } \\
\text { areas, especially increased } \\
\text { demand for residential and } \\
\text { commercial space }\end{array}$ \\
\hline
\end{tabular}

Until the 1800s, the Settlement of the Tbilisi was laid exactly where the channel of Mtkvari River is the narrowest, and the relief functioned as a natural barrier and allowed better protection of the city. Tbilisi was originally established as a compact city on both sides of the Mtkvari. However, it should be noted that the right bank of the Mtkvari was more populated than the left (Fig. 2). According to source analysis, economic activities, especially trade, were quite intensive during this period, which is confirmed by the caravans, hazelnuts, open and closed markets, food or household/agricultural markets reflected in the plans of Tbilisi in 1735 and 1800. It is also important to note the existence of a glass factory on the 1800 plan. However, the city was not infrastructurally equipped. Guldenstedt, who was in Tbilisi in the 1770s, also speaks about this. Tbilisi is characterized with narrow and disordered streets [9].

The essential peculiarities at this stage can be distinguished by three circumstances: 1) confinement by natural constraints; 2) The compactness of the city around the thermal waters was gradually being violated, and the river of development was already intersecting. Formation along the Mtkvari; 3) Existence of a significant area of green cover both inside the city and in its surroundings. There were gardens and vineyards in a large area. Thus, the city was characterized by a simple territorial structure. Thus, this period, the relief even served its original defensive function, and natural landscapes had not changed intensively, preserving a frame structure.

\footnotetext{
${ }^{2}$ Districts are listed under their current names
} 


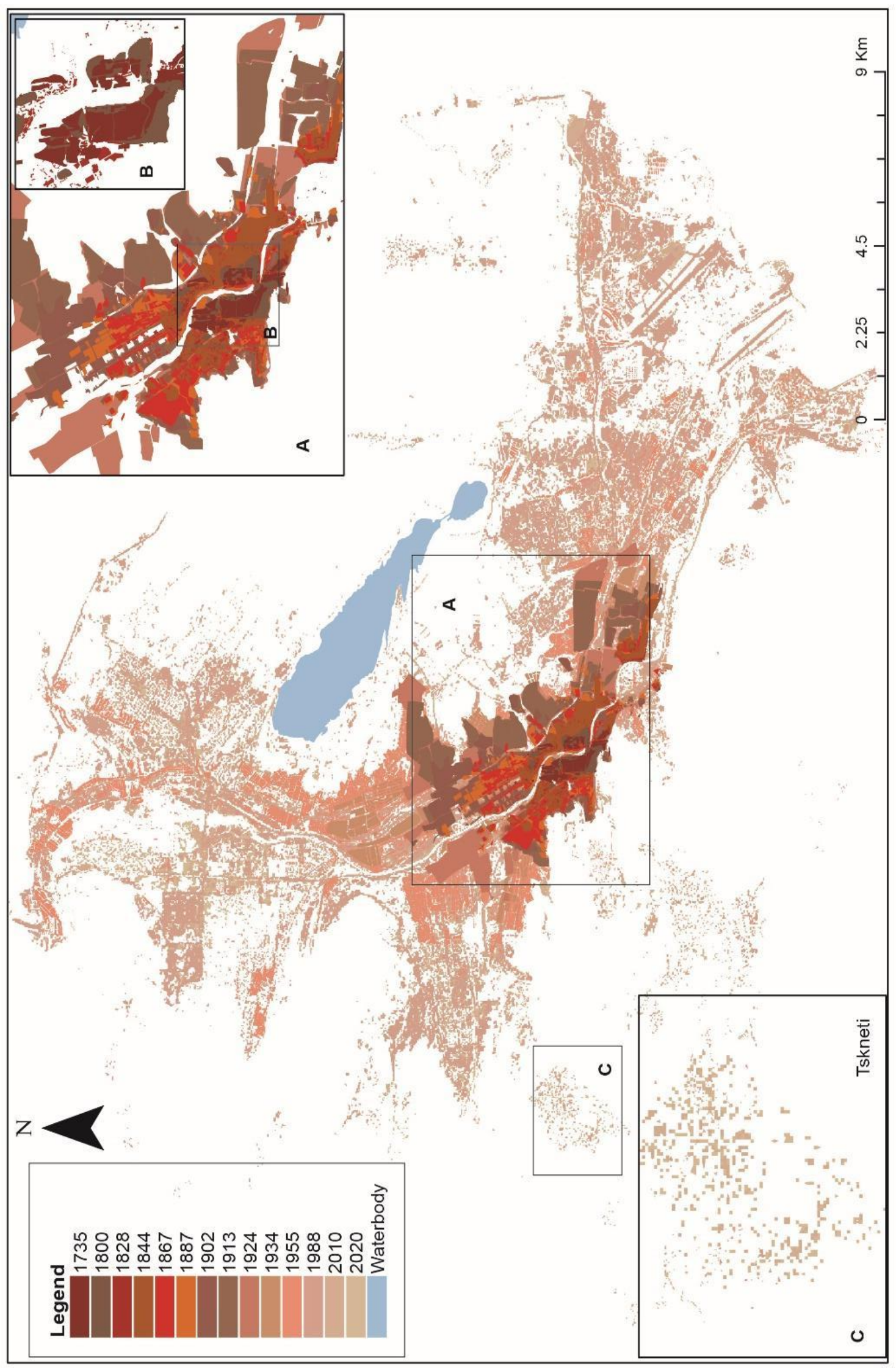

Figure 2. Urban sprawl in Tbilisi through history 
1800-1850s. At the beginning of the 19th century, Georgia became a part of the Russian Empire. The stabilization of the political situation and the increase of the local function contributed to an increase in the local population (Fig. 3). As a result, economic activity began to intensify. Tbilisi became the political, economic and cultural centre of the Caucasus, which increased the demand for residential, commercial, and industrial space, and led to urban sprawl. From Fig. 2, it can be seen that the city's expansion along the Mtkvari River was happening, and this trend was maintained throughout the nineteenth century. This expansion has been especially evident since the mid-nineteenth century. Carefully examining Figure 4, we can clearly see that sharp urban expansion began during 1809-1828. Between 1828 and 1844 the urban area doubled, as illustrated in Fig. 3. Based on the exact figure, it is evident that the reason for this was not a sharp increase in population. During this period, the construction of the current Isani District began, the settlement of Avlabari expanded, and urban expansion in the direction of modern Chavchavadze Avenue began. It appears adjacent to the river Mtkvari, parallel and transversely designed streets form rectangular quarters. At the same time, the architectural look of Tbilisi was changing: European-type buildings were emerging [10]. However, the development of new territories was slow. Due to the orography, the city could not develop equally in all directions, and it clearly took the form of length - along the river Mtkvari, to the north-west [9]. In contrast to previous development, for the first time, the relief became the primary reason why the city could not maintain its compact shape. However, as we mentioned in the first period, the city's situation did not improve in terms of infrastructure. It continued in the first half of the 19th century, which is the time that the linguist-orientalist Claprot said: "They can hardly reach each other." Also, the city's cleanliness was paid no attention. In History of Tbilis, we read, "the population of the city dumped all kinds of garbage wherever they could fly". Over time, however, they began to care about the appearance and communications of the city. The construction of squares began, which became permanent gathering places.

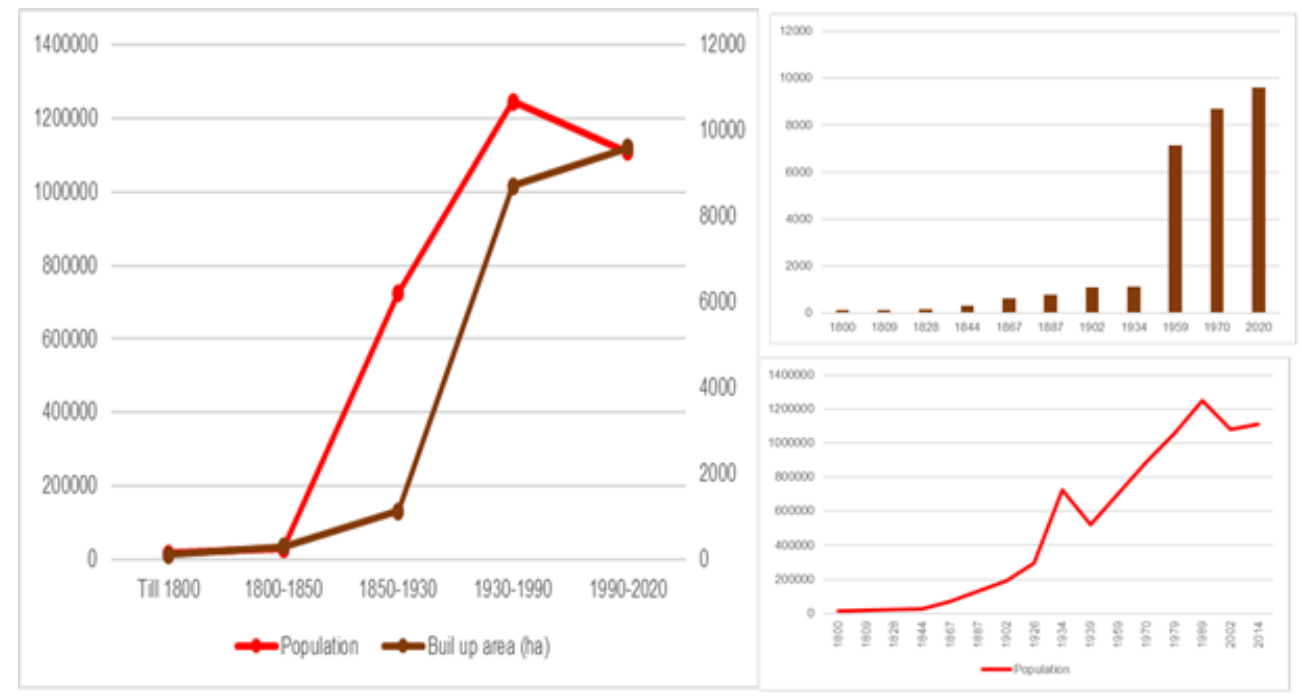

Figure 3. Changes in population and built up area of Tbilisi

A significant area was covered with greenery - gardens, vineyards, and vegetables during this period. At the beginning of the century, a German colony appeared in the area of Kuki - Alexanderdorf, which is now in the centre of the city. This name completely changed the existing network of winding streets in Tbilisi. A rectangular quarterly planning development emerged here.

1850-1930s are characterized by an even greater scale of socio-economic development, which is due to three important circumstances: 1) Tbilisi became a city of attraction for foreign merchants and artisans [10], 2) The railway was built in the 1890s, which encouraged the growth of development in the old area between the settlement and the railway line; 3 ) The capital became the most important educational center, where the first state university was founded (1918) and a number of educational facilities were opened; and 4) New bridges were built and for the first time mass urban transport ("Konka") was put into operation.

We observe from Fig. 3 that in 1844, compared to 1809, the population had increased by only 8,000. The picture is completely different between the data for 1844 and 1867. Data in Fig. 3 suggest that in 
this case, too, the built-up area doubled in the given period, although, unlike the previous period, the population actually doubled. As can be seen from Fig. 3, between 1867 and 1887 the population doubled again, although the increase in built up area was not so large. At the same time, at the end of the nineteenth century, a wave of urban expansion shifted to the left bank of the Mtkvari, which is also due to the relief factor.

The political processes developed at the beginning of the twentieth century in themselves have an impact on urbanization and comparing Figs. 2 and 3 indicates that from 1900 to 1934 the development grew very slowly. It should also be noted that population growth was more noticeable.

As a result of all this, there were already many reasons to expand the city and become an urban object, which affected both the city and its suburbs - urban lands were taking the place of agricultural lands. According to Tbilisi plans, compared to 1844, in 1924, the border area increased almost three times (from $3 \mathrm{~km}^{2}$ to $8 \mathrm{~km}^{2}$ ) (Fig. 2).

European-type buildings and industrial buildings were becoming more visible (for example, blacksmiths, either, soap, wood, and other factories, weapons factories, carpentry enterprises, blacksmiths, craftsmen, etc.). Although the northwest direction of the development continued to grow, the city's growth in the southeast direction toward Navtlughi was also significant.

Despite the rapid development described above, during this period, a significant amount of the city's green cover was still preserved, even in the city's central districts. For example, in the settlement of Kukia, where intensive urban development began in the 1950s, there were still orchards and vineyards. It is noteworthy that fragments of gardens are still preserved in the form of parks.

Another practical change would be observed in the fourth period, 1930-90s, which coincides with the rising period of Soviet rule. In terms of development, systematic urbanization was underway in Tbilisi at that time. An excellent example of this is the 1958-1960s construction of the Vazha-Pshavela quarter, with its wide streets and greenery. It should be noted that such urbanization has not taken place from the initial development of Tbilisi to the modern period, although it differs radically from international best practices. The area does not stand out artistically, though there are more free spaces, green areas, and children's play spaces [11].
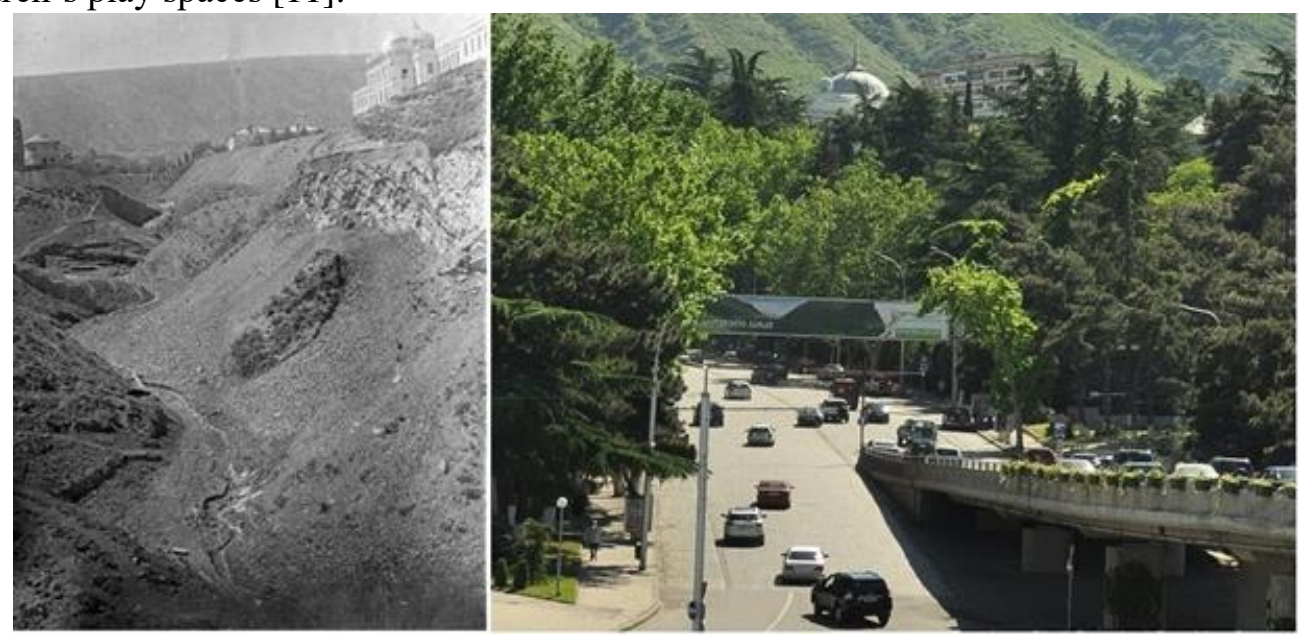

Figure 4. Varaz gorge - before transformation and after transformation

As the spatial needs of the city's inhabitants increased, so did the development of new areas - for housing, trade, enterprise, and communication. Accompanying this was the transformation of the natural environment impacting the relief, hydrography, and the landscape in general. An excellent example of this is the infrastructure work since the 1950s: the construction of riverbeds with large retaining walls and coastal roads, turning into collectors of rivers and dry ravines, etc., for example, Varazi Valley, where at present the river does not flow to the surface. (Fig.4.) [11].

This period can be conditionally divided into two parts. During the first half of the period, the builtup area increased six times, and the population grewrapidly. This has its explanation. After the end of World War II, a strong wave of industrialization began in the country, followed by the cultivation of 
industrial areas. The city's population grew rapidly, which increased the demand for housing and even promted the construction of new housing estates. During this period, the foundation was laid for the development of new neighbourhoods, particularly the existing agrarian areas in the current Metromsheni and Didi Dighomi settlements were transformed into a built-up area. The foundation is laid for the development of the territory of Didi Dighomi. During these twenty years, urban expansion shifted from the right bank of the Mtkvari to the left bank. In this case, the built-up area was expanded mainly at the expense of agricultural areas [12].

In 1934 Soviet authorities initiated the first master plan of Tbilisi, where the main priority was developing housing areas, regulating density, and improving the living conditions of city inhabitants. They proposed to develop the left and right banks of the river, but mostly the left bank. Industrialization and new factory development brought more people into the city, which needed accommodations. For this reason, new dwelling areas were constructed. Several new bridges were erected that improved the connectivity of both parts of the city. A new highway type road was proposed on both sides of the river, which also led to the city's further structural development. As mentioned in the research of [13], at the end of the 1950s, it was possible to see a significant shift to a new city structure. Soviet authorities initiated the micro-region development proposals. These were typical housing units developed as micro-regions, with the slogan "faster and cheaper." Every family had to have an independent dwelling unit, resulting in the construction of more housing units.

During this period, Saburtalo and Dighomi areas were introduced as extensive mass housing areas, although not fully established as were, later on, Gldani and Temka areas.

These processes became even more intense in the second half of this period. However, during the third master plan proposal (1949-1951- or 1950s), the group proposed expanding the city structure linearly and developing it toward the Tbilisi Lake, a man-made lake (created after the first master plan - 1934). The initial plan was to expand the city centre and connect the area to the newly developed housing near the Tbilisi sea. Unfortunately, this was never fulfilled.

In the 1960s-70s, due to the relief, the Tbilisi master plan design proposed to build one-two level housing units along the slope in the Vake and Saburtalo areas. Unfortunately, due to high costs and the problem with population density, the idea was never realized. The Saburtalo area, mainly the Nutsubidze area, was designed and constructed as high-rise buildings on a very harsh relief.

It should be noted that urban expansion was a more or less manageable process during this period and proceeded mainly according to pre-designed plans. In this particular case, we do not discuss how accurately these plans were implemented and the reasons for the failure to implement these plans to the end [14], which facilitated the construction of roads and connected certain areas of the city more closely. During this period, Vake and Saburtalo were connected, for which a specific section of the mountain slope was blown up, where Tamarasvili Street now exists.

Urban expansion continued for the next 20 years. During this period, the current Mukhiani and Mukhiani villas area were added to the built-up area. The development of the territory of Didi Dighomi became incredibly intense. Urban expansion intensified in the direction of the Tbilisi Sea and the Ponichala area, and the construction of Vazha-Pshavela Avenue continued. Even in this period, active urban expansion on the left bank of the Mtkvari was taking place mainly at the expense of agricultural areas.

In the 1980s, a wave of urban expansion swept across the right bank as well. The development of Nutsubidze plateau began, the built-up area increased in the direction of Vazha-Pshavela Avenue and Vashlijvari settlement.

In the next, fifth stage(1990s-present-day), the situation changed dramatically. The political situation in Georgia has changed since 1990. At this stage, there has been no urban development strategy in the country [11]. From this period, the uncontrolled urban sprawl process began in Tbilisi. The political, social, and economic crisis after the collapse of the Soviet Union in the 1990s led to a decline in the country's population. However, from this period, the unorganized urban sprawl began, mainly at the expense of suburban agrarian areas. 
In the 1990s, factories in Georgia ceased to operate, and many people in the regions lost their jobs. At the same time, cultural centres were closed. Lifestyle has changed radically. Consequently, migration to cities began - as a means of survival. In addition to industrial activities, trading was well developed in the cities, so the population found a solution by engaging in such activities. In addition to working within it, people need the cultural nourishment and hat the city has provided. This is evidenced by population statistics in rural and urban areas (Fig. 5).

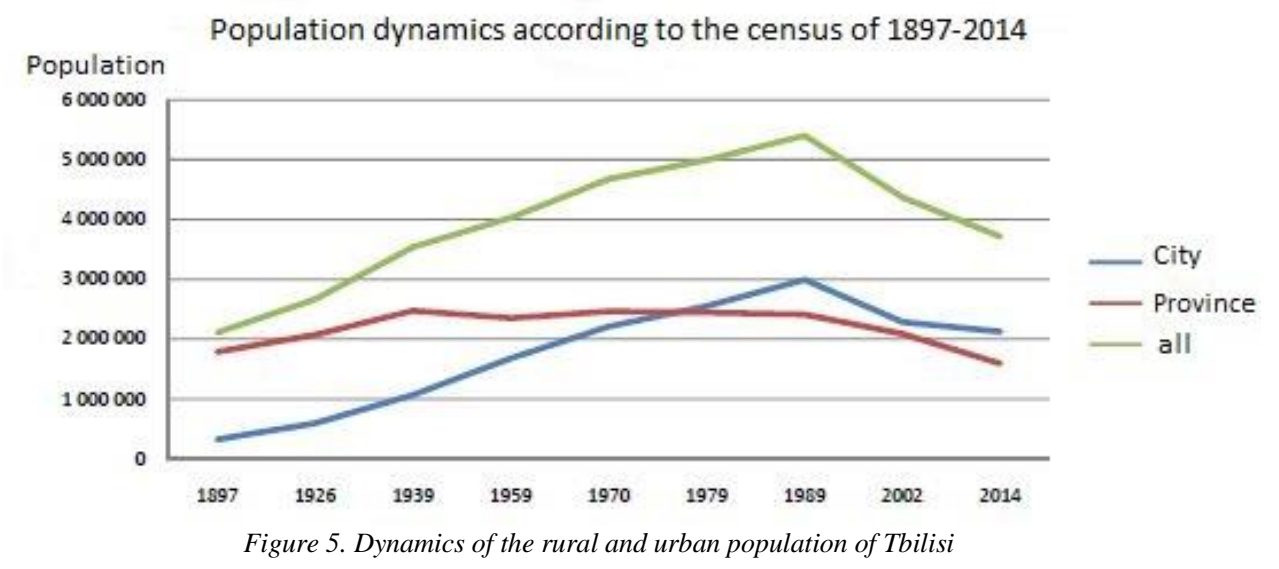

This process has been reactivated since the early 2000s. In this case, we can distinguish two directions: 1. Replacement of low-rise housing in the central districts with multi-story buildings, as was the case, for example, in the vicinity of the Sports Palace; 2. Development of new territories. In this case, the process of urban expansion became particularly active in the areas of Didi Dighomi and Ivertubani near Lake Lisi.

Although the population has shrunk since 2002 compared to 1989, urban sprawl is still underway. As a result, we have a city that stretches for about 33 kilometers along Mtkvari, which, in turn, increases the time spent on transportation and the demand for private cars as well. This is a big blow to the ecological condition of the city in terms of the quality of life in Tbilisi [15]. Consequently, the urban sprawl has presented in Tbilisi with negative effects, which does not make life here pleasant, although half of the country's population is concentrated in the capital. This fact has its logical explanation, although we will not dwell on this issue in this particular case.

All of the above circumstances have their logical explanation. In 2003, the government leadership in Georgia changed, prompting significant reforms. This further affected the urbanization process. At the beginning of the 19th century, $2 \%$ of the country's population lived in Tbilisi, and as of January 2021, $32 \%$ of the Georgian population resided within. This is relatively high, concerning the area of Tbilisi and causes congestion. It is interesting to consider what are the attraction factors when such numbers can even make life in the city uncomfortable.

All this is due to the fact that, unlike in previous decades, providing for the vital needs of the population (primarily their food) no longer requires the involvement of large numbers of people in agriculture and other agricultural activities. Today, cities offer more opportunities to the population exempted from agricultural activities, especially the young. Tbilisi is a very difficult socio-economic, political, and cultural space. Consequently, it is the centre of numerous human activities, more access to education, employment, entertainment and various services, which attract migration from rural areas. In 2006, villages and suburbs joined Tbilisi. To review the statistics of rural and urban population in Tbilisi in 1994-2007. The number of rural residents was invariably 0.1 (thousand) men. In 2007, 28.3 (thousand) men. This is related to the increase of borders. Until 2006, the area of Tbilisi was $356 \mathrm{~km}^{2}$, and from 2006 it was $502 \mathrm{~km} 2$, at the expense of the annexation of the bordering villages (Fig. 1). This fact has also affected the density and has moved to second place in the country with this figure, when the capital is experiencing a large workload overall. In addition, the growth of green areas is also observed at a time when construction is proceeding at a catastrophic rate.

In terms of urban renewal, the left bank of the Mtkvari is more congested than the right, which is related to the old historical sites on the right bank, such as Old Tbilisi, where construction bans are in 
place to preserve the appearance. It should also be noted that the city limits were raised from the right bank.

\section{Conclusion}

In conclusion, the situation in the villages and cities of Georgia creates a favourable environment for the urbanization "boom" (explosion) and overcrowding of cities, which means "mass" population approach to the city, primarily concerning Tbilisi. This creates problems such as unsystematic development and chaotic constructions, which negatively impact the natural environment and social conditions of the place.

As for the social problems that have arisen, the problem of employment is created in a congested city. Unemployed people engage in illegal, sometimes criminal, activities. There is a significant social load, traffic jams, the problem of parking.

In terms of the recommendation, we all need to talk about, proper urban planning is needed so as not to cause repeating problems for the citizens, and to make their living environment comfortable. It is also necessary to maintain more or less healthy natural environmental conditions. At the same time, attention should be paid to the retention of the rural population. This should be done not only by developing agriculture but also by developing the surrounding municipal centres, so that the population can at least partially receive the cultural or educational nourishment that draws them to the city.

\section{Competing interests}

The authors declare that they have no competing interests.

\section{Authors' contribution}

M.Ts. and N. Kh. conceived of the presented idea. L.G. and I. K. performed the analytic calculations. D.N. took the lead in writing the manuscript. All authors provided critical feedback and helped shape the research, analysis and manuscript.

\section{Acknowledgements}

This research [PHDF-21-1242] has been supported by Shota Rustaveli National Science Foundation of Georgia (SRNSFG).

\section{Authors' note}

In the process of working on the article, the administrative boundaries of Tbilisi were changed once again. These are minor changes; thus, the update was not included in the article.

\section{References}

[1] Jin, J., Gubbi, J., Marusic, S., \& Palaniswami, M. (2014). An information framework for creating a smart city through internet of things. IEEE Internet of Things Journal, 1(2). https://doi.org/10.1109/JIOT.2013.2296516

[2] Varzi, A. C. (2021). What is a City? Topoi, 40(2). https://doi.org/10.1007/s11245-019-09647-4

[3] Williams, T. (2014). Archaeology: Reading the City through Time. In Reconnecting the City: The Historic Urban Landscape Approach and the Future of Urban Heritage (Vol. 9781118383988). https://doi.org/10.1002/9781118383940.ch1

[4] Oueslati, W., Alvanides, S., \& Garrod, G. (2015). Determinants of urban sprawl in European cities. In Urban Studies (Vol. 52, Issue 9). https://doi.org/10.1177/0042098015577773

[5] Brilhante, O., \& Klaas, J. (2018). Green city concept and a method to measure green city performance over time applied to fifty cities globally: Influence of GDP, population size and energy efficiency. Sustainability (Switzerland), 10(6). https://doi.org/10.3390/su10062031

[6] Van Assche, K., \& Salukvadze, J. (2012). Tbilisi reinvented: Planning, development and the unfinished project of democracy in Georgia. Planning Perspectives, 27(1). https://doi.org/10.1080/02665433.2011.601611

[7] Gadrani, L., Lominadze, G., \& Tsitsagi, M. (2018). F assessment of landuse/landcover (LULC) change of Tbilisi and surrounding area using remote sensing (RS) and GIS. Annals of Agrarian Science, 16(2), 163- 
169. https://doi.org/10.1016/j.aasci.2018.02.005

[8] Tatashidze, Z. (2000). Tbilisi. In Z. Tatashidze, K. Kharadze, J. Kekelia, \& R. Khazaradze, Geography of georgia, Part 1, Physical Geography (pp. 200-207). Tbilisi: Metsniereba (in Georgian)

[9] Meskhia, Sh., Gvritishvili, D., Dumbadze, M., Surguladze, A. (1958). History of Tbilisi. Tbilisi: State Publishing House for Children and Youth Literature

[10] Ukleba, D. (1989). The nature of Tbilisi and its surroundings. Tbilisi: Soviet Georgia.

[11] Movement DOCU, (2021). Urban sprawl. Film, Bakuradze, A., Qadagishvili, E.

[12] Gadrani, L., Tsitsagi, M., \& Tielidze, L. (2019 Urban Landscape of Georgia (On the Example of Large Cities). Springer International Publishing. https://doi.org/10.1007/978-3-319-77764-1_6

[13] Van Assche, K., \& Salukvadze, J. (2012). Tbilisi: Urban transformation and role transformation in the post-Soviet metropolis. In Remaking Metropolis: Global Challenges of the Urban Landscape. $\underline{\text { https://doi.org/10.4324/9780203095485 }}$

[14] Asatiani N. (2015). Urban development problems in Georgia in 1960-1970. ARS Georgia, Series B. ISSN 1512-4088

[15] Alpaidze, L., \& Pace, R. (2021). Ecosystem Services Provided by Urban Forests in the Southern Caucasus Region: A Modeling Study in Tbilisi, Georgia. Climate, 9(11), 157. https://doi.org/10.3390/cli9110157 